\title{
INHIBITION OF FLOWERING OF MEXICAN- AND GUATEMALAN- TYPE AVOCADOS UNDER TROPICAL CONDITIONS
}

\author{
M. SEDGLEY ${ }^{1}$, P.B. SCHOLEFIELD ${ }^{2}$ and D.McE. ALEXANDER ${ }^{3}$ \\ ${ }^{1}$ CSIRO Division of Horticultural Research, GPO Box 350, Adelaide, South Australia \\ 5001 (Australia) \\ ${ }^{2}$ CSIRO Division of Horticultural Research, Private Mail Bag 44, Winnellie, Northern \\ Territory 5789 (Australia) \\ ${ }^{3}$ CSIRO Division of Horticultural Research, Private Mail Bag, Merbein, Victoria 3505 \\ (Australia)
}

(Accepted for publication 20 September 1984)

\section{ABSTRACT}

Sedgley, M., Scholefield, P.B. and Alexander, D.McE., 1985. Inhibition of flowering of Mexican- and Guatemalan-type avocados under tropical conditions. Scientia Hortic., 25: $21-30$.

Avocado trees of a range of cultivars growing in Darwin, northern Australia (average yearly maximum $33^{\circ} \mathrm{C}$, minimum $23^{\circ} \mathrm{C}$ ), were observed for flower and shoot development. Terminal buds of the cultivars 'Fuerte', 'Rincon' and 'Edranol' sampled in July were not floral. Buds which did not burst were sampled in September and they contained developing flowers with perianth primordia. Vegetative extension growth resulted from laterals proximal to the inhibited terminal buds.

Avocado trees of the cultivars 'Fuerte' and 'Hass' which had initiated floral buds were transferred to controlled environment chambers with $33^{\circ} \mathrm{C}$ day, $23^{\circ} \mathrm{C}$ night $(33 / 23)$ or $25^{\circ} \mathrm{C}$ day, $15^{\circ} \mathrm{C}$ night $(25 / 15)$ with a 12 -h photoperiod and photon flux density of $400 \mu \mathrm{mol} \mathrm{m} \mathrm{m}^{-2} \mathrm{~s}^{-1}(400-700 \mathrm{~nm})$. At $33 / 23$ the trees had fewer flowers and a shorter flowering period than at 25/15. Inhibited floral buds and lateral vegetative extension resulted at $33 / 23$, as observed in northern Australia. The unburst buds had developing flowers with perianth and stamen primordia.

The controlled environment experiments showed that the abnormal flushing behaviour of Mexican- and Guatemalan-type avocados growing in northern Australia was due to high temperature. Floral development was inhibited at the stage of stamen differentiation.

Keywords: avocado; flowering; flowering inhibition; Persea americana Mill; temperature.

\section{INTRODUCTION}

The avocado (Persea americana Mill.) is grown commercially in a number of countries, generally from $40^{\circ} \mathrm{S}$. Lat. to $40^{\circ} \mathrm{N}$. Lat, where the climates vary from temperate through subtropical to tropical (Ahmed and Barmore, 
1980). This range of climate tolerance within the species is due to the existence of three ecological races. The West Indian race is thought to have evolved in the tropical lowlands of Central or northern South America, the Guatemalan race in the Central American highlands and the Mexican race in the drier cooler areas of Central America and Mexico (Knight, 1980). In general, the Mexican- and Guatemalan-race avocados or their hybrids are grown in temperate and subtropical areas and West Indian types in the tropics (Bergh, 1975). Limitations to cultivation of the different races depend largely on the tolerated temperature range. West Indian-race avocados are severely injured by temperatures below freezing, and Mexican and Guatemalan types do not thrive under conditions of continuous high temperatures. In the latter case, the reluctance of these races to flower and fruit contributes to the problem.

In the commercial avocado growing area of the River Murray Valley in southern Australia (S. Lat. $34^{\circ}$ ), floral initiation in the 'Fuerte' cultivar occurs during April and May and anthesis during September and October (Alexander, 1975; Scholefield et al., 1985). Floral primordia arise in the axils of the bud bracts and the apex of the avocado bud generally remains vegetative (Reece, 1942; Schroeder, 1945, 1951; Jackson and Sweet, 1972; Scholefield et al., 1985). The floral axillaries develop ahead of the vegetative apex and following anthesis, continued vegetative growth occurs as the apex develops. The terminal buds and the lateral buds down the shoot all have the potentiality to become floral.

In this paper we report abnormal budburst and poor flowering behaviour of Mexican- and Guatemalan-type avocados under tropical conditions in northern Australia. The climate in this area is dry monsoonal tropics, with a dry season from April to September and a wet season from October to March. The average maximum and minimum temperatures are 33 and $23^{\circ} \mathrm{C}$, respectively, with little variation throughout the year (Australia, Bureau of Meteorology, 1975). In addition, we report controlled-environment experiments which have confirmed that floral budburst is inhibited by the continuous high temperatures experienced under these conditions. This abnormality has not been observed in the temperate and subtropical avocado growing areas.

\section{MATERIALS AND METHODS}

Five-year-old grafted avocado trees of the cultivars 'Fuerte', 'Rincon' and 'Edranol', growing near Darwin (S. Lat. 12 $27^{\circ}$ '), were observed for vegetative and floral growth. Terminal buds were sampled in July and September. They were bisected and fixed in 3\% glutaraldehyde in $0.025 \mathrm{M}$ phosphate buffer $\mathrm{pH} 7.0$, dehydrated through alcohols and embedded in glycol methacrylate. Longitudinal sections were cut at $5 \mu \mathrm{m}$ and stained with periodic acid-Schiff's reagent and toluidine blue $O$ for microscopic examination (Feder and O'Brien, 1968) for presence of floral development. 
A range of cultivars growing in avocado collections at research stations and grower properties near Darwin was examined for the presence of the growth abnormality pictured in Fig. 1b. Trees were rated as: 0, none evident; $\mathrm{L}$, low incidence; $\mathrm{M}$, medium incidence; $\mathrm{H}$, high incidence. Some branches on trees in experimental plantings were cinctured prior to anthesis, a practice reported to increase yields (Trochoulias and O'Neill, 1976), and observed following fruit harvest for the presence of the abnormality.

Two-year-old grafted avocado trees of the cultivars 'Fuerte' and 'Hass', which had been trained to 3 main shoots, were selected with a minimum of 5 floral buds as judged by their swollen external appearance. Prior to the experiment, the trees were maintained in a glasshouse with temperature conditions of approximately $20^{\circ} \mathrm{C}$ day and $10^{\circ} \mathrm{C}$ night, which was conducive to floral initiation (Buttrose and Alexander, 1978). Three trees of each cultivar were placed in growth cabinets with temperatures of $33^{\circ} \mathrm{C}$ day $/ 23^{\circ} \mathrm{C}$ night (Darwin temperatures) or $25^{\circ} \mathrm{C}$ day $/ 15^{\circ} \mathrm{C}$ night (temperatures under which normal floral behaviour occurs; Sedgley, 1977; Sedgley and Annells, 1981), both with a 12-h day (07.00-19.00) and a photon flux density of $400 \mu \mathrm{mol} \mathrm{m} \mathrm{m}^{-2} \mathrm{~s}^{-1}(400-700 \mathrm{~nm})$. The plants were kept well watered and were observed daily for number of flowers, number of floral buds bursting and total flowering period. At the end of the experiment, any unburst swollen buds were fixed and prepared for microscopy as described previously.

The 'Fuerte' cultivar is a predominantly Mexican type although it has some Guatemalan genes (Bergh, 1975). 'Hass' is a Guatemalan-type cultivar with up to a quarter Mexican genes (Bergh and Whitsell, 1974) and 'Rincon' and 'Edranol' are considered to be Mexican-Guatemalan hybrids (Bergh, 1975).

\section{RESULTS}

Darwin observations. - Swollen terminal buds were observed on the trees in July. Microscopic examination showed that the axillaries had commenced elongation but had not yet started to produce floral primordia (Fig. 1a). The buds continued to swell but very few flowered. In the majority of cases, the swollen terminal remained unburst and a lateral bud proximal to the terminal bud burst, usually as a vegetative shoot, and the branch continued to extend in this atypical manner (Fig. 1b). Microscopic examination of the unburst terminals sampled in September showed that they had floral axillaries with developing flowers with perianth primordia (Fig. 1c). The results were similar for the three cultivars, and none of the floral axillaries appeared abnormal in any way.

The results from the survey of the incidence of this budburst abnormality in avocado cultivars are presented in Table I. Those cultivars and seedlings of West Indian type exhibited less of the abnormality than the Mexican-and Guatemalan-type cultivars. Cinctured branches flowered and fruited better than the remainder of the trees but the budburst abnormality was still observed. 

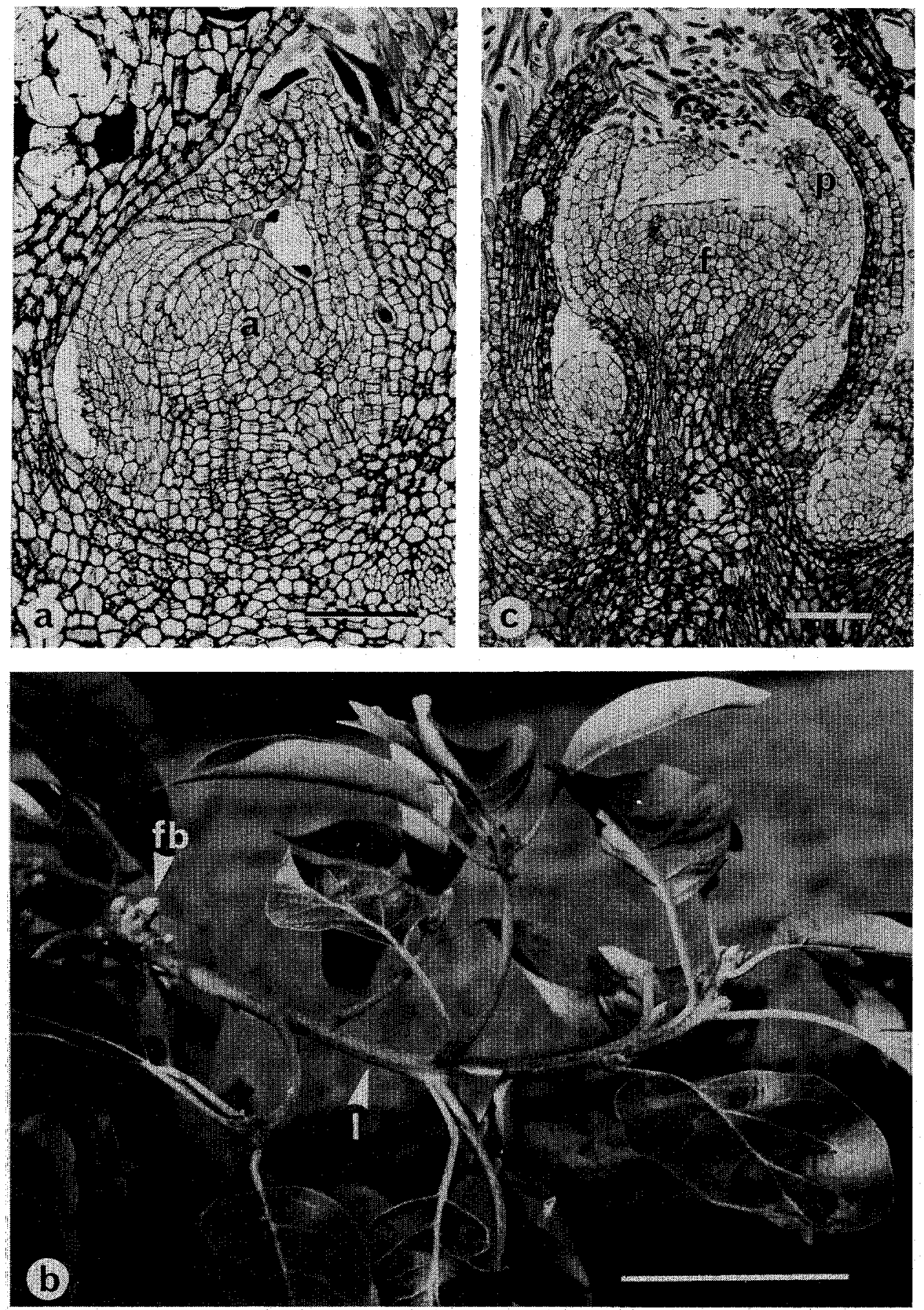
Controlled environment observations. - Under the warmer conditions of $33 / 23$, the plants flowered for a much shorter period and produced fewer flowers than under 25/15 (Table II). The 'Fuerte' cultivar was more sensitive to higher temperatures than 'Hass', as the number of flowers was reduced by $92 \%$ as compared with $53 \%$ for 'Hass'. There were four reasons for the reduction in flower number. The first was observed in 'Fuerte' only and involved the abscission of floral branches of burst floral buds prior to anthesis. The second reason was the fewer flowers per bud at $33 / 23$ than at $25 / 15$ in both cultivars (Table II), indicating that some floral axillaries of the bud did not burst. Thirdly, some of the swollen apparently floral, buds did not burst at all and, fourthly, more floral buds were produced during the experimental period in both cultivars at 25/15 than at 33/23.

At $33 / 23$, the flowering period was reduced by $77 \%$ in 'Fuerte' and by $52 \%$ in 'Hass' and the trees, particularly of the 'Fuerte' cultivar, underwent a vegetative flush from lateral buds along the shoots (Fig. 2a). Microscopic examination of the unburst swollen buds showed that they were floral. Stages of development observed ranged from axillaries which had just started to produce floral primordia (Fig. 2b) to developing flowers with stamen primordia (Fig. 2c).

\section{DISCUSSION}

Avocados grown in controlled-environment conditions simulating the temperatures experienced in northern Australia produced the same inhibition of floral development and abnormal vegetative extension growth as observed on trees in Darwin. Floral initiation and early development appeared normal, but further development was generally halted at the stage just prior to stamen development in the flowers. It is possible that the differentiation of the sex organs may be particularly sensitive to high temperature, as is the case during later stages of floral development in many other species (Randolf, 1932; Sax, 1937; Langer and Olugbemi, 1970; Saini and Aspinall, 1982; Saini et al., 1983). It was interesting to note that the vegetative apex of the inhibited terminal buds did not burst. The inhibited development of the floral axillaries appeared to limit development of the vegetative apex in the same bud. This led to a tree of abnormal appearance, with numerous wispy lateral shoots rather than strong leaders.

The plants used in the controlled-environment experiments had initiated floral buds under conducive conditions. The most advanced of the floral buds

Fig. 1. Avocado trees in Darwin. (a) 'Fuerte' bud harvested on 5 July 1980 showing elongated axillary meristem (a). Bar represents $100 \mu \mathrm{m}$. (b) 'Fuerte' shoot showing the terminal floral bud ( $\mathrm{fb}$ ) which has failed to burst and the proximal vegetative lateral (l) which has burst to continue the extension of the shoot. Bar represents $10 \mathrm{~cm}$. (c) 'Edranol' bud harvested on 15 September 1980 showing axillary meristem with developing flower (f) with perianth primordia (p). Bar represents $100 \mu \mathrm{m}$. 


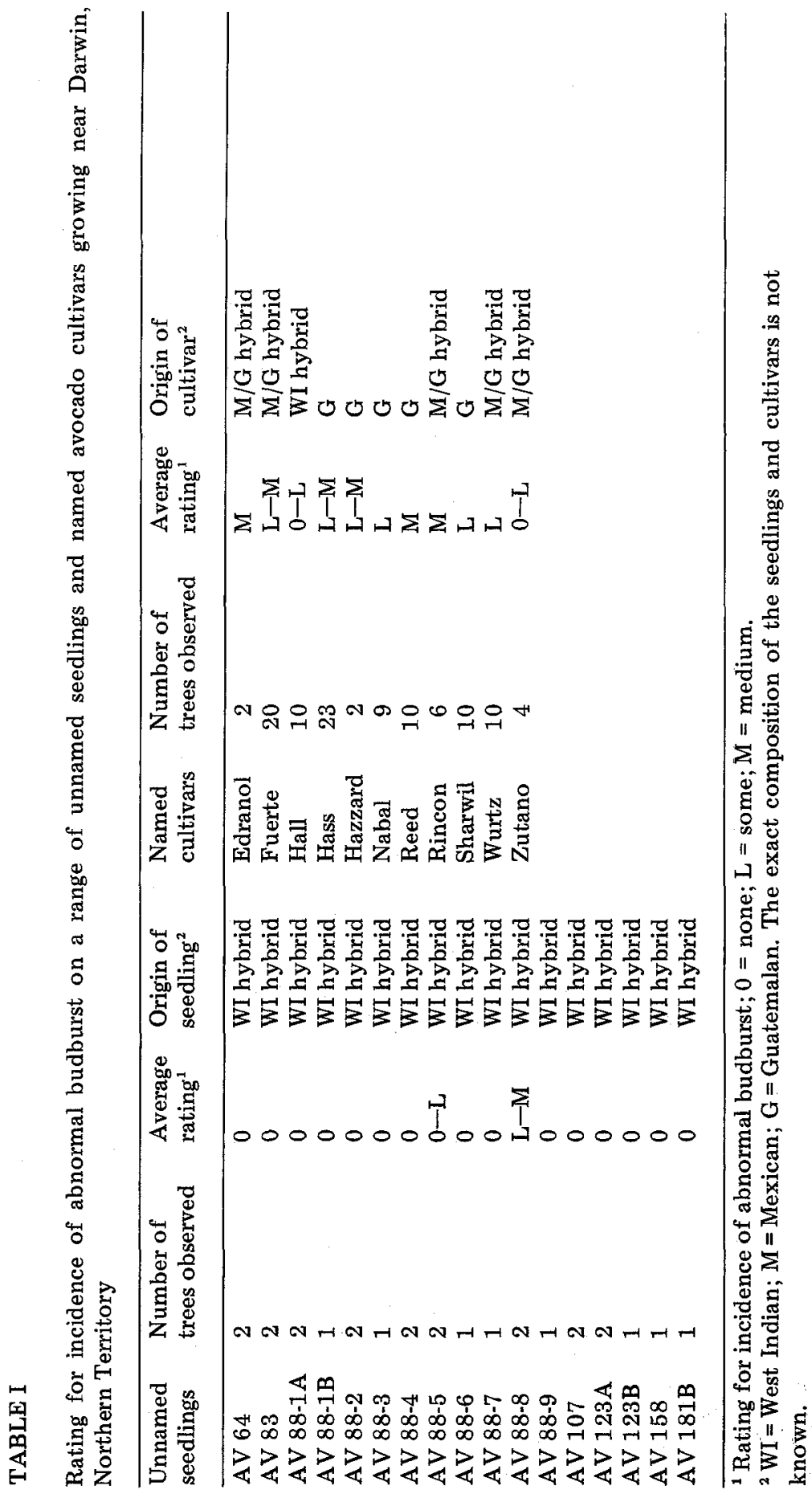


TABLE II

Flowering data for the avocado cultivars 'Fuerte' and 'Hass' under different temperat ure conditions

\begin{tabular}{|c|c|c|c|c|c|c|}
\hline $\begin{array}{l}\text { Temperature } \\
\text { conditions } \\
\text { (day/night) } \\
\left.{ }^{\circ} \mathrm{C}\right)\end{array}$ & Cultivar & $\begin{array}{l}\text { Flowering } \\
\text { period } \\
\text { (days) }\end{array}$ & $\begin{array}{l}\text { Total } \\
\text { number of } \\
\text { flowers }\end{array}$ & $\begin{array}{l}\text { Total } \\
\text { number of } \\
\text { buds flowering }\end{array}$ & $\begin{array}{l}\text { Number } \\
\text { of flowers } \\
\text { per bud }\end{array}$ & $\begin{array}{l}\text { Number } \\
\text { of unburst } \\
\text { floral buds }\end{array}$ \\
\hline $33 / 23$ & Fuerte & 12.0 & 66.9 & 3.4 & 21.5 & 3.8 \\
\hline $33 / 23$ & Hass & 14.8 & 679.2 & 8.8 & 77.5 & 2.6 \\
\hline $25 / 15$ & Fuerte & 52.0 & 857.5 & 16.0 & 53.6 & 0 \\
\hline $25 / 15$ & Hass & 30.9 & 1456.7 & 12.7 & 114.1 & 0 \\
\hline \multicolumn{7}{|l|}{ D } \\
\hline$(P=0.05)$ & & 4.1 & 454.0 & 0.2 & 32.7 & 1.0 \\
\hline
\end{tabular}

Data were transformed to square roots for analysis as treatments had widely different variances.

had already burst prior to the start of the experiment, so many buds would have passed the stage of stamen differentiation at which development appeared to be inhibited by high temperatures. Thus it appears that flowering can proceed once this stage has been passed. It is likely that under $25 / 15$, extra floral buds were initiated during the course of the experiment. Schroeder (1951) reported floral initiation between 6 and 8 weeks prior to anthesis in the cultivars 'Fuerte', 'Mexicola' and 'Dickinson' growing in California.

Under southern Australian conditions (S. Lat. $34^{\circ}$ ), floral initiation was observed in April and May and anthesis occurred during September and October following a cool winter $\left(16.1^{\circ} \mathrm{C}\right.$ max., $4.8^{\circ} \mathrm{C}$ min.; Scholefield et al., 1985). Under the warmer winter conditions of southern California (Schroeder, 1951), flowering can occur from November (early winter) through to June (early summer). Thus the relatively long floral development period in southern Australia is probably due to slow growth conditions. Under the high temperatures of northern Australia, flowers may be produced at any time, although most flowering occurs during July-September. The floral development period, in those cases where flowering occurs, appears to be very short, as buds harvested in July were not floral.

A comparison of the maximum and minimum temperatures in some avocado-growing areas in Australia (Table III) shows that high daytime temperatures can be experienced in most regions during the period of floral development. This is particularly true of the Mareeba (Atherton) area in north Queensland, where there is a flourishing industry based on Mexicanand Guatemalan-type cultivars. The major difference between Darwin and the avocado-producing regions is in the night temperature. It is possible that high night temperature or high average diurnal temperature is more important than the daily maximum. This is considered to be likely, as our glasshouse observations indicate that only a short period of a few days at continuous high temperature is sufficient to produce an irreversible inhibition of budburst. 

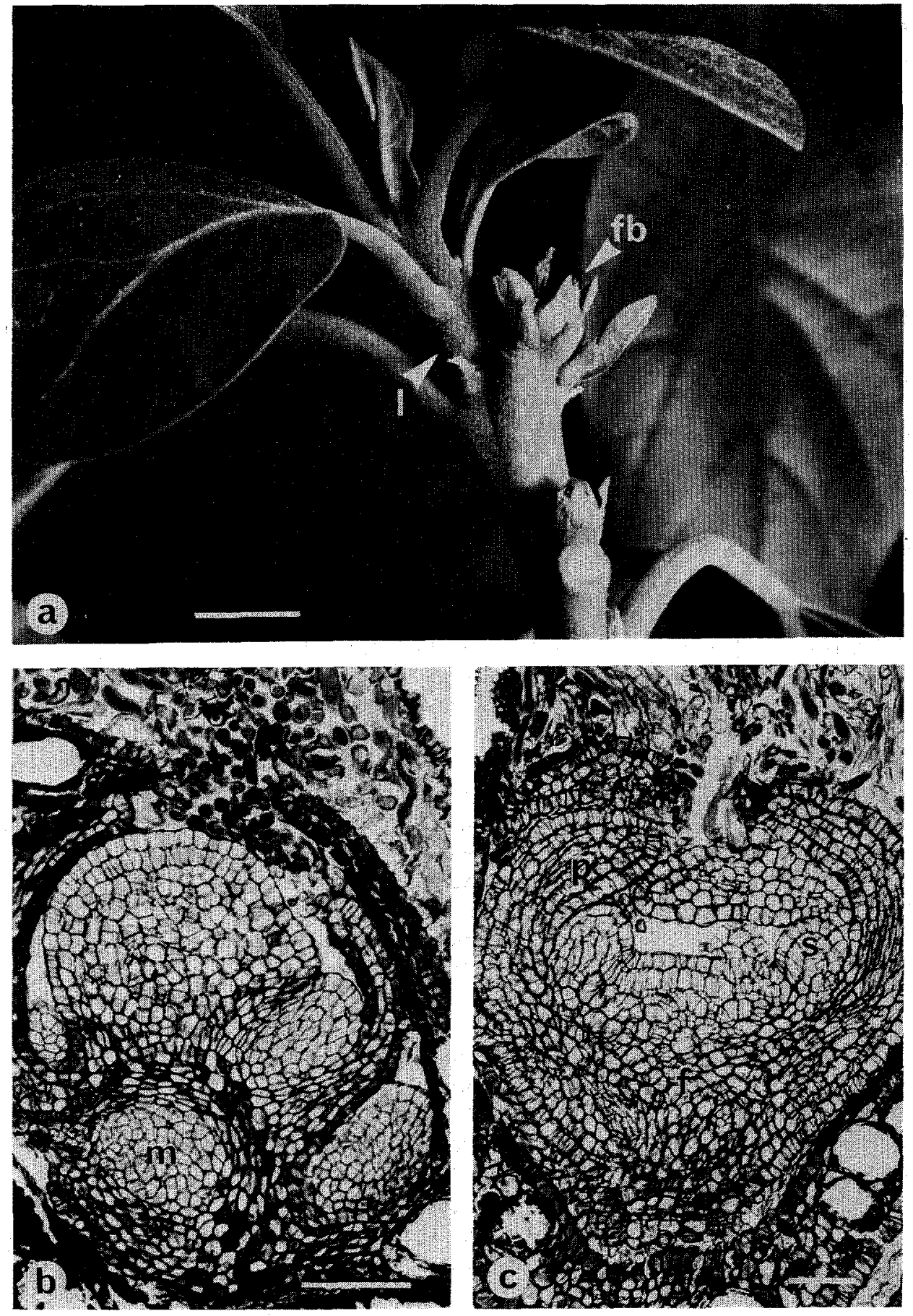
TABLE III

Temperature data for some avocado growing areas in Australia during the period of floral development (Australia, Bureau of Meteorology, 1975)

\begin{tabular}{|c|c|c|c|c|c|}
\hline & & $\begin{array}{l}\text { Merbein, } \\
\text { Victoria }\end{array}$ & $\begin{array}{l}\text { Alstonville, } \\
\text { New South Wales }\end{array}$ & $\begin{array}{l}\text { Mareeba } \\
\text { (Atherton), } \\
\text { Queensland }\end{array}$ & $\begin{array}{l}\text { Darwin, } \\
\text { Northern } \\
\text { Territory }\end{array}$ \\
\hline April & $\begin{array}{l}\text { Mean max. }\left({ }^{\circ} \mathrm{C}\right) \\
\text { Mean min. }\left({ }^{\circ} \mathrm{C}\right)\end{array}$ & $\begin{array}{l}23.9 \\
10.5\end{array}$ & $\begin{array}{l}24.4 \\
15.0\end{array}$ & $\begin{array}{l}28.4 \\
17.1\end{array}$ & $\begin{array}{l}32.7 \\
23.9\end{array}$ \\
\hline May & $\begin{array}{l}\text { Mean max. }\left({ }^{\circ} \mathrm{C}\right) \\
\text { Mean min. }\left({ }^{\circ} \mathrm{C}\right)\end{array}$ & $\begin{array}{r}18.8 \\
7.0\end{array}$ & $\begin{array}{l}21.2 \\
12.3\end{array}$ & $\begin{array}{l}26.6 \\
14.8\end{array}$ & $\begin{array}{l}31.9 \\
21.8\end{array}$ \\
\hline June & $\begin{array}{l}\text { Mean max. }\left({ }^{\circ} \mathrm{C}\right) \\
\text { Mean min. }\left({ }^{\circ} \mathrm{C}\right)\end{array}$ & $\begin{array}{r}16.0 \\
4.9\end{array}$ & $\begin{array}{r}18.8 \\
9.7\end{array}$ & $\begin{array}{l}25.1 \\
12.9\end{array}$ & $\begin{array}{l}30.6 \\
19.9\end{array}$ \\
\hline July & $\begin{array}{l}\text { Mean max. }\left({ }^{\circ} \mathrm{C}\right) \\
\text { Mean min. }\left({ }^{\circ} \mathrm{C}\right)\end{array}$ & $\begin{array}{r}15.5 \\
4.4\end{array}$ & $\begin{array}{r}18.4 \\
8.6\end{array}$ & $\begin{array}{l}25.3 \\
11.2\end{array}$ & $\begin{array}{l}30.3 \\
18.9\end{array}$ \\
\hline August & $\begin{array}{l}\text { Mean max. }\left({ }^{\circ} \mathrm{C}\right) \\
\text { Mean min. }\left({ }^{\circ} \mathrm{C}\right)\end{array}$ & $\begin{array}{r}16.8 \\
5.2\end{array}$ & $\begin{array}{r}20.2 \\
9.8\end{array}$ & $\begin{array}{l}26.6 \\
11.7\end{array}$ & $\begin{array}{l}31.2 \\
20.3\end{array}$ \\
\hline September & $\begin{array}{l}\text { Mean max. }\left({ }^{\circ} \mathrm{C}\right) \\
\text { Mean min. }\left({ }^{\circ} \mathrm{C}\right)\end{array}$ & $\begin{array}{r}19.9 \\
7.3\end{array}$ & $\begin{array}{l}21.5 \\
11.5\end{array}$ & $\begin{array}{l}28.1 \\
12.9\end{array}$ & $\begin{array}{l}32.5 \\
22.9\end{array}$ \\
\hline October & $\begin{array}{l}\text { Mean max. }\left({ }^{\circ} \mathrm{C}\right) \\
\text { Mean min. }\left({ }^{\circ} \mathrm{C}\right)\end{array}$ & $\begin{array}{l}24.5 \\
10.0\end{array}$ & $\begin{array}{l}24.6 \\
14.2\end{array}$ & $\begin{array}{l}30.7 \\
15.6\end{array}$ & $\begin{array}{l}33.3 \\
24.9\end{array}$ \\
\hline
\end{tabular}

The yields of fruit on most of the cultivars growing near Darwin have been low, and this has been attributed to poor flowering. Cincturing caused more flowering, but not by preventing the budburst abnormality from occurring. The cincturing or girdling treatment increases carbohydrate levels which stimulates floral initiation in some species (see Jackson and Sweet, 1972). Our observations suggest a lack of carbohydrate build-up in the trees, possibly due to high respiration rate within the canopy under the hightemperature conditions. This may be the cause of the abnormal budburst.

Cultivars of the West Indian type of avocado exhibited less abnormality during burst of floral buds than Mexican/Guatemalan types. However, their productivity was still unacceptable. The West Indian type of avocados are more tropical in their requirements, and we believe that some cultivars of this group will eventually prove suitable for the development of a small avocado industry in north-west Australia. Some of these cultivars are presently under test.

Fig. 2. Avocado trees at 33/23. (a) 'Fuerte' shoot showing terminal floral bud (fb) which has failed to burst and proximal vegetative lateral (1) which is bursting to continue the extension of the shoot. Bar represents $1 \mathrm{~cm}$. (b) 'Hass' bud showing elongated axillary meristem which has started producing floral meristems (m). Bar represents $50 \mu \mathrm{m}$. (c) 'Fuerte' bud showing developing flower (f) with perianth (p) and stamen (s) primordia. Bar represents $50 \mu \mathrm{m}$. 


\section{ACKNOWLEDGEMENTS}

Part of this study was funded by The Rural Credits Development Fund of the Reserve Bank of Australia, and this support is gratefully acknowledged. E.A. Lawton and M. Blesing assisted with the photographic preparation.

\section{REFERENCES}

Ahmed, E.M. and Barmore, C.R., 1980. Avocado. In: S. Nagy and P.E. Shaw (Editors), Tropical and Subtropical Fruits. AVI Publishing, Westport, CT, pp. 121-156.

Alexander, D.McE., 1975. Flowering times of avocados in the Murray Valley. J. Aust. Inst. Agric. Sci., 41: 264-267.

Australia, Bureau of Meteorology, 1975. Climatic averages. Australian Government Publishing Service, Canberra.

Bergh, B.O., 1975. Avocados. In: J. Janick and J.N. Moore (Editors), Advances in Fruit Breeding. Purdue University Press, Indiana, pp. 541-567.

Bergh, B.O. and Whitsell, R.H., 1974. Self-pollinated Hass seedlings. Calif. Avocado Soc. Yearb., 1973-74: 118-126.

Buttrose, M.S. and Alexander, D.McE., 1978. Promotion of floral initiation in 'Fuerte' avocado by low temperature and short daylength. Scientia Hortic., 8: 213-217.

Feder, N. and O'Brien, T.P., 1968. Plant microtechnique: some principles and new methods. Am. J. Bot., 55: 123-145.

Jackson, D.I. and Sweet, G.B., 1972. Flower initiation in temperate woody plants. Hortic. Abstr., 42: 9-24.

Knight, R., Jr., 1980. Origin and importance of tropical and subtropical fruit crops. In: S. Nagy and P.E. Shaw (Editors), Tropical and Subtropical Fruits. AVI Publishing, Westport, CT, pp. 1-120.

Langer, R.H.M. and Olugbemi, L.B., 1970. A study of New Zealand wheats. IV. Effects of extreme temperature at different stages of development. N.Z. J. Agric. Res., 13: $878-886$.

Randolf, L.F., 1932. Some effects of high temperature on polyploidy and other variations in maize. Proc. Natl. Acad. Sci. U.S.A., 18: 222-229.

Reece, P.C., 1942. Differentiation of avocado blossom buds in Florida. Bot. Gaz., 104: $323-328$.

Saini, H.S. and Aspinall, D., 1982. Abnormal sporogenesis in wheat (Triticum aestivum L.) induced by short periods of high temperature. Ann. Bot., 49: 835-846.

Saini, H.S., Sedgley, M. and Aspinall, D., 1983. Effect of heat stress during floral development on pollen tube growth and ovary anatomy in wheat (Triticum aestivum L.). Aust. J. Plant Physiol., 10: 137-144.

Sax, K., 1937. Effect of variations in temperature on nuclear and cell division in Tradescantia. Am. J. Bot., 24: 218-225.

Scholefield, P.B., Sedgley, M. and Alexander, D.McE., 1985. Carbohydrate cycling in relation to shoot growth, floral initiation and development and yield in the avocado. Scientia Hortic., 25: 99-110.

Schroeder, C.A., 1945. The avocado inflorescence. Calif. Avocado Soc. Yearb., 1944: $39-40$.

Schroeder, C.A., 1951. Flower bud development in the avocado. Calif. Avocado Soc. Yearb., 1951: 159-163.

Sedgley, M., 1977. The effect of temperature on floral behaviour, pollen tube growth and fruit set in the avocado. J. Hortic. Sci., 52:135-141.

Sedgley M. and Annells, C.M., 1981. Flowering and fruit-set response to temperature in the avocado cultivar 'Hass'. Scientia Hortic., 14: 27-33.

Trochoulias, T. and O'Neill, G.H., 1976. Girdling of 'Fuerte' avocado in subtropical Australia. Scientia Hortic., 5: 239-242. 